\title{
Paper Evidence in Toronto Imprints, 1798 to I84I
}

\author{
Patricia Lockhart Fleming
}

IN HIS INTRODUCTORY PAPER AT THE I979 ANNUAL MEETING OF THIS Society, a meeting devoted to the subject of descriptive bibliography, Roy Stokes identified paper as a bibliographical feature overlooked by most early bibliographers and insufficiently studied by many contemporaries. ${ }^{1}$ Certainly the literature of paper evidence, although distinguished, is not extensive. ${ }^{2}$ It includes, nonetheless, first-rate thrillers such as the Carter and Pollard enquiry, which exposed forged literary documents through an analysis of materials used in manufacture of the paper, and W.W. Greg's demonstration of false dating by a seventeenth-century printer of Shakespearian plays, based on observation of the watermarked paper. More recently, Allan Stevenson determined the date of an early missal by recording wear to the paper moulds, a method of analysis noted but not developed by Greg.

No such drama has marked my study of the paper used by early Canadian printers, but a good deal of solid evidence about book making has been gathered through close physical observation of paper, supplemented by historical research. Some of the paper can be traced to place of manufacture by using watermarks and related evidence. Patterns of supply and use, established by careful recording and analysis, permit comparison to practices in other countries as well as providing a basis for speculation about correct dating. Leaders in the trade can be recognized both as manufacturers and users of paper, with new relationships and alliances clarified. And at certain critical periods, developments in papermaking indicate the economic, political, and social climate in which printers and publishers were working.

The study included about 560 imprints: books and pamphlets printed in York and Toronto from 1798 , when the first press arrived, to. $184 \mathrm{I}$, the year Toronto ceased to be the capital of Upper Canada. ${ }^{3}$ Broadsides, items intended for limited or private circulation such as invitations and circulars, and newspapers with their supplements and extras were all excluded. Monthly serials were included since they are not numerous and, although issued in parts, were numbered as one volume. ${ }^{4}$

Additional copies were examined whenever possible although scarcely at the rate recommended by 'bibliography's grey eminence in Charlottesville'. 
It must be noted, however, that some titles are exceedingly rare, possibly held as unique copies; many are scarce; only a handful are found by the dozen. During the present study fewer than half of the imprints were seen only once; more than one third were examined in three or more copies.

The framework for this analysis of paper evidence is chronological: the import years from 1798 to 1826 , the period of handmade Canadian paper from I826 to 1832 , and that of machine made paper after 1832 .

During the import period supplies of printing paper were insecure and unsatisfactory. In 1802 John Bennett apologized to readers of the Upper Canada Gazette:

he laments the present absolute necessity of publishing on paper of such an inferior quality, but has spared neither pains nor expence to obviate that inconveniency in future, by actually importing from London a stock of good paper. (January 30, I802)

Bennett's successors in the government printing office, the only shop in the capital for more than twenty years, commented regularly on their difficulties with paper. In I823 for example Charles Fothergill reported 'the shipwreck of his winter's supply of paper'.6 The great variety of paper used in the ninety or so titles examined from the import years is evidence of the printers' dilemma.

The two basic papers were both in use: laid, the traditional paper with a conspicuous pattern of chain and wire lines; and wove, a smoother paper made on wire mesh which was introduced in England about 1755 by James Whatman and widely adopted for printing during the fourth quarter of the eighteenth century. In the United States wove paper, first manufactured about I80o, dominated the market by I8I5.

In the Toronto sample more than half the imprints dated between 1798 and I826 are on wove paper with the earliest printed in I8or. Although most of these papers are not marked, eighteen specimens of imported wove paper show either, or both, date and mill or maker's name or initial. Laid paper, used in more than one third of the titles, is fairly evenly divided between marked and unmarked, although there is a clear difference in the period of usage with almost all the unmarked laid paper used prior to I8I2. A small sample of early newspapers also shows a mixture of laid and wove papers. The official Upper Canada Gazette for 1798 and 1799 is printed on laid paper; most issues from I8I8 to I826 are on wove although in I82I issues for April, May, June, August, and September are on laid paper, some watermarked. Laid paper was used again in the spring of 1824 . Scattered issues of the Observer (Toronto's first non-government newspaper) dated I820, I822, I823, and 1825 are on wove paper while the Colonial Advocate, the capital's third paper, was printed on both laid and wove in 1825 and 1826.

Proceeding with due caution into the intricacies of watermarks one can identify some of the makers whose paper was used by Toronto printers. A 
basic difficulty in the examination of printed materials, some cropped in binding and rebinding, lies in distinguishing enough of the mark to record it. Nineteenth-century papers are, moreover, somewhat neglected in the standard British sources. And because there is clear evidence that printers in Toronto imported American paper, attribution to either a British or an American mill merely on the basis of initials is unwise. Initials were commonly used as marks in the American paper trade as well as the British and both followed custom with marks such as posthorn, fleur-de-lis, and Britannia. A dozen of the British mills and makers supplying the Toronto market before I826 can, however, be clearly identified: Annandales, J. Bates, John Fellows, J. Green at Barsham Mill, Magnay and Pickering, Iping Mill in Sussex, J.C. Radway, Ruse and Turner, Smith and Allnutt, Stains, John Whatman's Turkey Mill, and G. Wilmott.

The incidence of marked paper in individual titles suggests patterns of supply by revealing the stock of paper available to the printer for a particular job. Some shops had a uniform stock or a run: in Letters of an American Loyalist in Upper Canada each quarto gathering is a wove sheet marked along the short edge Magnay \& Pickering London. ${ }^{7}$ Laid paper watermarked with Britannia, countermarked $\mathrm{KIL}^{\mathrm{N}} / \mathrm{I} 82 \mathrm{I}$ was used throughout two folio government reports of $\mathrm{I} 823$ and $1824 .{ }^{8}$ Other imprints show through the use of remnants, random assortments of paper, the jumble of stock used by some Toronto printers. The I80I Journal of the House of Assembly, for example, was printed on five lots of wove paper, one unmarked, the others dated 1793, I798, 1799, and I800.' Several titles including the York Almanac for I82I and the Statutes of the same year combine laid and wove papers. ${ }^{10}$ When several copies of a single work show further variation, the diversity in paper stock is even more noteworthy. An example is John Beverley Robinson's Letters of I823 on the Canada trade which combines in one copy two I82I wove papers, one marked M, the other J Whatman/Turkey Mill, and a wove of I8I5 marked A. ${ }^{11}$ Another copy has the Whatman paper of I82I and two woves of I820, one by Smith and Allnutt and the other by Ruse and Turner. ${ }^{12} \mathrm{~A}$ third has one gathering each of the I82I Smith, the I82I Whatman, and the 1820 Ruse, the I8I5 marked A, and another wove marked BATH/1819. ${ }^{13}$

The dates included as part of the marking in some papers are accepted as generally reliable for early nineteenth-century British paper since, by an act of Parliament in 1794, British papermakers were allowed a drawback of excise duty on the export of paper only if it was marked in the sheet with date of manufacture. A survey by Edward Heawood of the length of time between making and use of more than eighty dated papers of this period revealed an average interval in England of a little under three years. ${ }^{14} \mathrm{~A}$ similar comparison using Toronto imprints before $\mathrm{I} 826$ shows that thirteen dated laid papers were used on average slightly more than two years after manufacture, while 
sixteen dated wove papers were not printed until nearly five years had elapsed. The laid paper used for newspapers and a sample of broadsides averages more than five years between making and use.

To get some notion about the origins of all the unmarked paper used in Toronto during the import years, one must turn from an examination of the paper itself to a scrutiny of the texts which were printed on it. As noted previously the early king's printers were explicit in naming Britain as the source of their paper supplies. There is other evidence too that the government ordered paper both in writing and printing grades from England. One series, the manuscript acts and sessional papers sent before 1826 from Toronto to the Colonial Office and now preserved in the Public Record Office in London, was recorded on paper manufactured by twenty-five documented British makers and only one American, David Buel of Rensselaer County, New York.

Independent printers who set up shop in the twenties were more likely to patronize the thriving mills of New York State, particularly after completion of the Erie canal in 1825 . John Carey, proprietor of the first non-government press and publisher of the Observer from May of 1820 , refurnished his shop in New York in 1824; it is probable that his purchases in the United States included paper. Toronto's third press, established late in I824, belonged to William Lyon Mackenzie, who had begun the Colonial Advocate at Queenston in May of 1824 and contracted for printing in the United States until the issue dated September 30 when he wrote,

We believe this Advocate to be as rare a curiosity as any newspaper that ever was printed in the world! The first side was printed in the American Republick, and this in the Colonial Dominions of King George 4 th. We do not know that any ONE Newspaper, other than this number, has been printed in rwo different countries, since the art of type setting was first invented. Our friends may rest assured, that both sides of the Advocate will, from henceforth, be printed on this side of the Niagara.

(Colonial Advocate, September 30, 1824)

Mackenzie's use of American paper at that time is further indicated by his offer to accept payment for the Advocate in 'Paper Rags: White and Coloured Linen \& Cotton Rags' (Colonial Advocate, August 19; October 28, 1824); these could no doubt be exchanged for paper at one of the mills in New York State. Answering critics in the capital who claimed that his journal was an American publication, Mackenzie charged that the government printer, Charles Fothergill, 'prints in York our laws and Gazettes on brown paper of America' (Colonial Advocate, July I, I824).

One reason for this practice was no doubt financial: American paper was entering duty free while English manufacturers paid two and one-half percent of value at Quebec and other ports. An act was passed, however, the following 
year in the Imperial Parliament imposing 'duties payable upon Goods, Wares, and Merchandize, not being of the Growth, Production, or Manufacture of the United Kingdom, or of any of the British Possessions ... imported into any of the British Possessions in America or the West Indies'. ${ }^{15}$ On books and paper the duty was thirty percent, a significant increase for the printers: 'Last year we had acts of the English Legislature enabling us to import printing paper and raw hides duty free: this year counter acts imposing heavy duties on these articles' (Colonial Advocate, December 8, I825).

Further evidence about the flourishing trade in paper between Upper Canada and the United States can be found in some of the rhetoric surrounding the establishment of a native paper industry. ${ }^{16}$ The desirability of local manufacture had been voiced as early as 1815 when the editor of John Cameron's Upper Canada Almanack called for 'I paper mill'. ${ }^{17}$ When he was editor of the York Almanac in 1823 Charles Fothergill wrote: 'There are many Manufactories of a domestic nature in which large capitals are required, the want of which is at present seriously felt by all classes of persons in the Province'; among those he specified were paper mills. ${ }^{18}$

William Lyon Mackenzie also took up the cause of a paper industry at the outset of his publishing career:

Paper. This is an article that, if it were manufactured in the Province, would be all saved to the country. United States printing paper comes into this Province duty free. If the government had offered liberal encouragement to a paper maker he would have saved us $\{3000$, Halifax a year. We speak now of Upper Canada. The printers here, say that they print only al together rooo reams a year of printing paper: there is $£$ Iooo saved. Then Iooo reams of writing paper is another $£ 1000$ in pocket. Then blue paper, cartridge paper, pasteboard, wrapping paper and the like. (Colonial Advocate, June 3, 1824)

In Toronto the following year he added:

Upper Canada Paper Mill. Mr Hollywell of this town talks of erecting a paper mill, if he does so he will deserve every protection to the home manufacture that the legislature can afford. - Even a bounty in such a case would be well applied. Moreover if his paper prove as good as his strong beer, there is little doubt of its finding a ready market.

(Colonial Advocate, April r8, 1825)

Later in the same year Toronto papers carried notice of a meeting to be held on December 16 'to take into consideration the propriety of establishing a paper mill in some eligible situation, as near the capital as possible' (Upper Canada Gazette, December I5, I825; Colonial Advocate, December I5, I825). According to Mackenzie, 'A proposal will be laid before the meeting for a person of great respectability, who will, under certain considerations, engage to have a Paper mill in operation before the first of May next. The paper to be charged at Rochester prices' (Colonial Advocate, December 15, I825). The notice ended, 
'Resolutions, having for their object the formation of a company for the above purpose, will be submitted to the meeting and such members of the Legislature as are desirous of encouraging domestic manufactures, are respectfully requested to attend' (Upper Canada Gazette, December 15, 1825).

Mackenzie was deeply involved in the planning as a series of letters addressed to him by James Crooks demonstrates. Crooks, another enterprising Scot, owned mills at Flamborough West above Dundas, where Mackenzie had kept a shop before moving to Queenston. On December 12th Crooks wrote to Mackenzie continuing a recent conversation and outlined proposals which 'if you [WLM] think proper you may lay before the meeting'. Crooks expressed confidence in the scheme:

I think no person in Upper Canada could so effectually give effect to their instruction than I can, as my creek is excellent clear water $\&$ a sufficiency of it at all times for such a mill. The access by Land and Water from all parts of the Province is easy and will be completely convenient when the Steam Boat Canada is afloat as she will come twice a week to Burlington Bay.... I have already a mill which can be converted into a paper one by Ist May next.

He hoped to have 'such a Mill as Mr Peck' (probably Everard Peck of Rochester), but declared himself unable to withdraw 'too much capital' from other business and suggested that loans would be required for the first two years. ${ }^{19}$ Instead Mackenzie drafted a petition for a five hundred dollar bounty and, according to his later recollections, 'got it numerously signed' (Mackenzie's Weekly Message, March I7, I860). On December I8, I825 Mackenzie's petition was read in the House of Assembly and referred to a select committee. ${ }^{20}$

Letters from Flamborough West continued to arrive; Crooks wrote on December 27, 'I do not know a thing that would pay better than a Paper Mill', and added, 'You have been at great pains collecting information regarding such an establishment and have been equally free in communicating them for which individuals as well as the public ought to be much obliged to you'. $\mathrm{He}$ wrote again on January Io, I826, asking for information, acknowledging that 'no other person had collected so much information about it as you had'.

The select committee considering Mackenzie's petition reported by bill, first read on January I6, and passed on January 27,1826 by the House of Assembly and Legislative Council, entitled 'An Act to grant to His Majesty a sum of money for the encouragement of manufacturing paper in the Province. ${ }^{21}$ The premium was set at $£ 125$.

Advertisements for rags were already appearing in Mackenzie's paper and finally on March 23, I826 he announced, 'The most important item of news in this journal today is Col. Crooks's advertisement, stating that he has determined to erect a paper mill, or rather to convert to that purpose a building already erected': 
The Subscriber having in view the erection of a PAPER MILL at this place, to be in operation in the course of the month of May ensuing, solicits the patronage of the Public in supplying RAGS sufficient to keep the same in full employment, for which he will give as high a price as is usually given by the Paper Makers in the adjacent parts of the United States.... The advantages to this Colony from the establishment of a PaperMill, are so obvious and so numerous, that the Subscriber hopes that persons, to whom the value of RAGS may be no object, will (from patriotic motives) lend their assistance in securing a domestic supply; otherwise one great object in establishing such a manufacture, namely, that of keeping the money among the colonists will be defeated.

(Colonial Advocate, March 23, 1825)

The letter to Mackenzie in which Crooks enclosed the text of this advertisement described an unsuccessful attempt to hire away a foreman from an American mill, and his next move: 'My plan is to wait a week or two till the canal is open, then to proceed to Troy where ... I [can] get a foreman, screens \&c. \&c. and under his direction have the machinery put in.' He also urged Mackenzie on in his efforts to collect rags:

I have reason to hope I shall be assisted by all your Brethren of the Type ... as to yourself, I cannot think you will be so unnatural as to destroy a child of your own rearing - for certainly you have done almost, indeed I may say all that has been done to secure to the Province this great benefit. ${ }^{22}$

Instead of travelling to the United States personally, James Crooks trusted an agent well acquainted with the American trade to find him a foreman and 'apparatus'; some of the latter he described to Mackenzie: 'I have sent the size of the paper you wish for the Advocate in order that the suitable molds may be made for it'. ${ }^{23}$ He himself stayed in Flamborough West to concentrate on the mill, reporting on April Io, 'Messrs Abbott \& Taylor both Scotch Millwrights who have put up many Paper Mills, will be here tomorrow from Queenston ... but whether to stay or not I cannot yet say.'

Editorially Mackenzie urged his readers to support the enterprise:

Colonel Crooks's intended paper mill does himself as well as the legislature great honour - him for his enterprize, them for their liberality. - The Legislature of Nova Scotia lent their aid to a similar undertaking in that province sometime since, - and it now succeeds so as to abundantly reward the proprietor. May it be so here. Every rag ought to be saved for the paper mill, and the good lady as she looks at her well filled basket, may say to herself 'In saving these tattered and worn out garments I am collecting the chief material for a Bible or a Testament, a Dictionary or a Geography. I am adding, in every rag, a new page to some useful work that may benefit my children or the sons and daughters of my country.' (Colonial Advocate, March 30, I826)

But if one paper mill would be an advantage to the province, why not two, particularly if the second were at the capital? In the same issue Mackenzie speculated about improvements for Toronto: 
an act incorporating this city is much wanted ... a church clock, with a steeple 150 feet high, to set it in, and bells, to be rung twice a day, as in Kingston, and Ancaster: for the encouragement of order and regularity, would make the capital a little more lively; nay more, a paper mill might then be established in York and the course of the Don wholly altered!!! (Colonial Advocate, March 30, 1826)

This was not the first time a mill near Toronto had been proposed; shortly after the meeting the previous December, Timothy Street of Streetsville had offered a mill site on the Credit River to the first person to erect a paper mill there. The notice had emphasized the profitability of such manufactures 'so extensively and advantageously carried on in England, Ireland, Scotland and the United States, (even within 500 yards of the Colony)' (Colonial Advocate, December 29, 1825$)$. When a paper mill for Toronto was announced it was not on the Credit to the west, but on the Don, east of town:

The Subscribers, having entered into a co-partnership, for the purpose of converting the DON MILL into a PAPER MILL, and having most part of the millwright work done, and also a considerable stock of Rags collected, they will lose no time in completing it and carrying it into operation.

One of the partners, having had many years experience in the business, both in England and the United States, they flatter themselves that they will be able to make a good article, which they intend to sell as cheap as it can be had from the State of New York. (Colonial Advocate, April 20, I826)

The subscribers were Robert Stonehouse, the papermaker, and John Eastwood and Colin Skinner who had been operating a grist mill for several years; both had married into the Helliwell family, millers and brewers on the Don.

James Crooks did not appear to be disturbed by the possibility of competition when he wrote to Mackenzie less than a month later,

I know not how the York folk propose to get their apparatus for their Paper mill but I found much difficulty in getting mine and indeed had to go all the way to Jersey for it -I am getting on very well and hope to make my promise to the Public good ere the month is out, this 'entre nous'. What I have got is excellent \& if the sizes I have got of Moulds to make Paper do not suit I have made arrangements so that any size that may be wanted hereafter will be forwarded to me upon writing for them. ${ }^{24}$

His 'excellent' product was in the hands of the public late that summer:

We have much pleasure in presenting to our patrons this number of our paper, on a sheet, the manufacture of Upper Canada, which we trust they will find on examination, not to be inferior in any respect, to that, which we have heretofore offered them, and in the selection of which we took some pains. This specimen of the manufacture of our enterprising friend James Crooks, Esq. of Flamborough West, from whom we have received our supply, is such, as we have no doubt will insure to him that patronage which his exertions so justly merit. (Upper Canada Gazette, September 2, I826) 
The paper is wove, unmarked, of even, fairly coarse texture, heavy substance, and cream colour. After one unsuccessful submission to the Legislature of samples of his paper in October, James Crooks was awarded the $£ 125$ premium in December of 1826.

Mackenzie reported in April that the Crooks mill was in full operation and added two weeks later, 'We have now the prospect before us of a full and regular supply of paper within the province. The Colonial Advocate, the Journals of Assembly, and many of our jobs, are printed on paper made at Flamboro' West, U.C.' (Colonial Advocate, April 26, 1827). Readers of the Colonial Advocate were urged to support home manufacture as well:

Mr Crooks's establishment at Flamboro' West is deserving of every encouragement from the people of this province. Not only ought the stores to take in rags for its use, but there they also should purchase their writing paper. While in the mill on Monday week, we saw writing foolscap getting ready for the home market ... [which] will be sold at \$3 and $\$ 4$ per ream ... as cheap as the Rochester paper, and far below the price we pay in Montreal. We are glad to learn that $\mathrm{Mr}$ Crooks is getting customers for printing paper in Montreal ... (Colonial Advocate, July 4, 1827)

As for the Don Mill it was said to be 'under way' by April (Colonial Advocate, April I2, I827); in July Mackenzie wrote,

It is with feelings of pleasure and satisfaction, that we announce to the public that $\mathrm{Mr}$ Eastwood \& Co.'s paper mill on the Don near this town, is in complete operation, and that it is the intention of the proprietors to be guided as closely as possible by the Rochester prices. This is what we have long desired to see - and we believe that Messrs. E. \& Co. will find a good article and reasonable profit their best and most permanent interest. (Colonial Advocate, July 26, 1827)

He elaborated within a fortnight:

About three miles out of town in the bottom of a deep ravine, watered by the river Don, and bounded also by beautiful and verdant flats, are situated the York Paper Mills, Distillery and Grist Mill ... We went out to view these improvements a few days ago and returned much gratified with witnessing the paper manufacture in active operation.

(Colonial Advocate, August 9, 1827)

The proximity of this mill to Toronto was a great advantage; Mackenzie had complained about the problem of transportation from the Flamborough West mill. James Crooks delivered paper to Burlington Beach, but if no boats were sailing along the shore to Toronto, Mackenzie was oblıged 'to hire the mail stage to go to the beach, six miles off its route, and bring us paper' (Colonial Advocate, June 28, 1827). He continued to use Crooks's paper nonetheless, apologizing again for transportation problems the following year: 'Being disappointed, owing to the badness of the roads, of a supply of large imperial 
paper from Flamboro' West, we have left out a portion of the advertisements and issued a half sheet' (Colonial Advocate, April ro, 1828).

With two mills in the province Toronto printers were assured a reasonably steady supply of paper. The thirty percent tariff on paper legally imported from the United States added financial incentives to patriotic motives in supporting domestic manufacture. As far as is known neither Crooks nor Eastwood and Skinner marked the paper produced in their mills. Part of the explanation may be the absence from Upper Canada of a paper tax or duty regulating production and distribution. As with unmarked paper imported before 1826 evidence about use must again be gathered from the text and not the paper itself. Mackenzie, seldom reticent about his projects, continued to emphasize his use of Canadian paper; Robert Stanton, the king's printer, who presented James Crooks's paper with a flourish in the Upper Canada Gazette in 1826 , advertised his patronage of Canadian mills both in the twenties and thirties. Probably the most consistent supporters of the Don Mill were its own proprietors, Eastwood and Skinner; when they began to publish textbooks and almanacs there was no question about the source of their paper. An English author, Henry Cook Todd, who arrived in Toronto in 1832 and published a Canadian edition of his Manual of Orthoepy at the Guardian office the following year, was as enthusiastic as the Canadians themselves: 'this edition, including paper and binding, is the entire production of that infant capital; thus proving, in no trifling degree, the striking advantages of unrestricted industry.' Under $\mathrm{p}$ for paper in the text he added, 'There is no tax in Canada upon paper, newspapers, or advertisements. ${ }^{25}$

The House of Assembly, which had encouraged the founding of the industry with a premium, continued to support local manufacture. The contract for printing the Journal for 1830 specified 'The whole to be printed on the best quality of Demi paper, of Canadian manufacture'. ${ }^{26}$ In 1832 a payment of $£ 54$ $5 \mathrm{~s}$ was made to 'Eastwood for Journals of the last Session (paper)'27; contingencies for $1833-34$ included $£ 1465 \mathrm{~s}$ to 'Eastwood for paper for Journals.' ${ }^{28}$ The

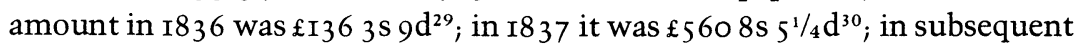
years lists of expenditures were abridged and this information no longer given.

Reports of local societies provide similar evidence. In I835 the Upper Canada Religious Tract and Book Society paid Eastwood and Skinner $£ 25$ Ios 'for Paper on Account of Almanacs ${ }^{\prime 31}$; that same year the Toronto Auxiliary Bible Society paid them $£$ I I 8 s for 'Paper for Indian Translation.' ${ }^{32}$ During testimony before a committee of the House of Assembly inquiring into trade and commerce, John Eastwood stated in March of 1835 that 'We manufactured paper last year to the value of 9000 dollars and upwards.' ${ }^{33}$

An alternate view of the successful development of papermaking in Upper Canada is provided by customers who expressed dissatisfaction with the 
product. The industry was scarcely launched before Mackenzie himself complained, 'This number is printed on an imperial sheet of Upper Canada paper, at five dollars and a half per ream. We think a finer sheet might be offered at that price, but the paper makers think otherwise' (Colonial Advocate, May 8, I828). He wrote at length from London in 1832 :

I have just received the Advocate of the 12 th July. It has but one fault. - The paper is detestable. They would refuse it here to wrap up brown sugar with. It is a little fairer than the ink, and but very little. I am sorry to perceive that Messrs Eastwood \& Skinner would offer such miserable paper to any printing office. Surely the difference of profit to them can be no great object! The paper is actually coarser than one of the earliest numbers of the Observer, a work apparently coeval with the invention of printing and paper making. - The papyrus from the old mummy of Thebes in Egypt, 4000 years old, is fair when placed beside the impoved [sic] productions of my friends of the Don Mills in America in the year of grace 1832 , with all the aid they can invoke from Acid and Alkalies, Chloride of Lime and Oil of Vitriol! (Colonial Advocate, October II, 1832)

But when the quality improved Mackenzie said so: 'the paper ... is creditable to Mr. Eastwood's establishment - it is fair, strong, and substantial - I wish he would always send as good paper' (Colonial Advocate, December 20, I832). He appears not to have done so, for the following spring Mackenzie, still in London, commented, 'I have just seen another copy of the Guardian - it is just as heavy again as the Advocate, and the paper the same price. Ah! Mr. Eastwood, Mr. Eastwood! It's a difficult thing for a greedy man to be a straightforward man in his dealings' (Colonial Advocate, April I4, 1833). Even when he returned to Toronto Mackenzie could not get a grade of paper which pleased him:

The paper furnished us by Mr Eastwood this and last week is very thin and dark coloured. We are sorry for it, but it is a fact that neither by remonstrances nor punctual payments can we persuade that gentleman regularly to supply us with a good article. Competition is wanted. (Colonial Advocate, January 18, 1834)

He was even more vehement in 1837 as publisher of the Constitution:

We ought to apologize for the wretched rag on which this impression and the last is printed. The usual weight of the newspaper sent us is from 90 to roo lb per bundle. Why Mr. Skinner has attempted to make the same size with materials weighing only $72 \mathrm{lb}$ per bundle we know not, but it is promised to be remedied next week. (Constitution, September 13, I837)

His final comment appeared a month before the rebellion, while he was gathering support in the countryside and meeting with fellow rebels in Toronto: 
We are glad to be able to inform our readers, that the excellent, strong sheet of paper this day presented to them is, like the Editor's coat home made. It is of the manufacture of Eastwood and Skinner. (Constitution, November 8, 1837)

Despite the proximity of the Don Valley Mill to Toronto, Eastwood and Skinner did not have a monopoly in the capital. Mackenzie was their customer but it is clear that other printers still patronized the original mill. The second issue of the Royal Standard, 'the first daily newspaper ever published in Upper Canada,' declared 'the Paper is also of Canadian Manufacture, and is made at the Establishment of the Hon. James Crooks ... at Flamborough' (Royal Standard, November II, I836).

Both mills also faced continuing competition from imported paper; a much publicized incident involving Egerton Ryerson and the Christian Guardian took place in I830. He labelled it 'The Paper Affair' and began his explanation, 'All that we deem necessary to say on this subject, we will now lay before our readers.' Two full pages $(43 \times 30 \mathrm{~cm}$.) follow. Apparently public attention was first roused by a charge carried in rival newspapers that the 'Reverend Editors' had been 'doing a little Smuggling in a "Christian" way' by importing 'Sixty Reams of "good Christian" paper' from the United States but paying duty on only thirty. Ryerson explained,

Our subscribers will recollect that the paper on which we have furnished them weekly instruction and intelligence, for the first three or four months, was of rather an inferior quality and would not in many instances answer the purpose of a common reading, much less to be preserved in files and bound, as was the wish of a majority of our subscribers....

We stated these things to the manufacturer from whom we purchased our supply of paper.... He replied that he could not get stock to furnish us with better paper. Accordingly, goaded by the daily complaints of our correspondents, we hastened to make enquiries, and engaged 60 reams of paper from an establishment between 160 and 200 miles from Youngstown. (Christian Guardian, April 17, 1830)

The sixty reams arrived at Niagara in thirty bundles; a series of misunderstandings resulted, including an assumption by the Collector of Customs that a bundle was a ream; the paper was seized but released after intervention by the Attorney General. A letter sent to Ryerson from the Collector of Customs reads, 'I had learned the circumstances of the detention of your paper from Mr Eastwood, the paper manufacturer at York.' Apparently Eastwood kept a jealous eye on the printers. Another incident was reported in I832:

On Monday last, Mr Eastwood, paper maker, came into our office, where our workmen were busy printing the Christian Almanac, and a fit of jealousy happening to seize him, 
lest the paper on which they were printed might be contraband goods, (as the Tract Society did not get their paper from his factory) took up the top sheet which we had wet down, and which was somewhat stained, and unhesitatingly pronounced it American paper, and accordingly went and lodged a complaint with the Collector of Customs. (Colonial Advocate, November I, 1832)

The Toronto Society had in fact obtained the paper from the London Tract Society and presented documents in proof. John Eastwood, displeased at being branded an informer, explained that he acted from duty and necessity: 'As to my being selfish or jealous I shall not put that into the scale opposite the Almanack Maker's patriotism, who prefers going to a foreign country to purchase that which can as well be had at home' (Colonial Advocate, December 6,18321 .

Despite both duty and duties Toronto printers continued to use imported paper when they needed finer grades. Charles Fothergill, an early advocate of a native paper industry in 1823 , echoed his original call for 'manufactories of a domestic nature' in his 1839 Almanac but updated it by specifying 'improved Paper Mills, (none but paper of an inferior quality being as yet manufactured in the province) $)^{\prime 34}$

Among twenty-five examples of marked paper both laid and wove used for printing between 1829 and I84I are the products of some well-known British mills: T. Edmonds, Edwin Morbey, I. and I. Smith, J. and J. Town, J. Webster, John Whatman, and G. Wilmott. A small sample of broadsides, all on laid paper, adds two more documented mills, Afonwen in Wales and John Livesey. During this period the paper was used quite promptly after manufacture, within approximately two years in most cases. The majority of the imprints using imported paper come from the presses of Robert Stanton, the king's printer and the capital's most prolific publisher.

Although the impossibility of attributing unmarked paper to a place of manufacture has been stressed, there is one brief period when Canadian paper can be distinguished with some certainty on the basis of physical evidence. This is during the period when hand moulds were replaced by papermaking machines. Experiments, begun in France in the 1790 ond transferred to London at the beginning of the nineteenth century, had resulted in widespread mechanization of the papermaking industry in Britain by the end of the first quarter of the century. In America the first papermaking machine was in use in 1817 , but it was not until 1829 that Eastwood and Skinner undertook mechanization of their mill and petitioned the House of Assembly to be allowed to import machinery free of duty. In March of the following year a bill allowing them a drawback of duties to a total of $£$ I25 received Royal Assent. The legislators acknowledged the 'necessity of introducing Machinery from the United States in order to perfect their Manufacturing Establishment, 
and thereby enable them to furnish paper of such quality and at such prices as will render it unnecessary to have recourse to foreign countries for the supply of that necessary article. ${ }^{35}$ A substantial purchase of American machinery was negotiated in 1832; Public Accounts show that Eastwood and Skinner were allowed in June of that year $£ 544 \mathrm{~S}_{2} \frac{1}{2} \mathrm{~d}$ 'being the amount of duties paid ... on Paper Machinery.' ${ }^{36}$

Both the Upper Canada Gazette and the Colonial Advocate switched from hand to machine made paper in the late summer of 1832 . The Courier of Upper Canada had also made the change by winter of the same year. Machine made paper with the clear evidence of seams was used in several other Toronto imprints of 1832 including the Statutes; by 1833 it was in common use. The date of mechanization at Flamborough West is not known, although the change had certainly taken place by 1836 :

The Subscribers having refitted their Paper Mill, and procured the most approved machinery, are able to supply Printing and Writing Paper of the best quality and on the most advantageous terms ... James Crooks \& Co. (Correspondent $€$ ) Advocate, March 3 , I836)

Upper Canada also had a third or ghost paper mill mentioned in two separate references. The first occurs in a letter from William Lyon Mackenzie published in the Colonial Advocate in I832 stating simply that 'Upper Canada contains 3 paper mills' (July I9, I832). The second is by Henry Cook Todd, who had commented on the Toronto mill in his first book and who wrote in Notes upon Canada ... MDCCCXXXV, 'There are three provincial paper-mills, Eastwood, Brown, and Hon. W. Crooks. ${ }^{\prime 37}$ This third mill was most probably the one at St. Andrews in Argenteuil, Lower Canada. Built originally by a group of New Englanders between 1803 and I805, the mill had passed, by the end of the decade, into the control of James Brown, a Montreal stationer. He manufactured there a wide range of papers including Royal and Demy Printing, Foolscap and Quarto Post as well as the common wrapping, blotting, tea, and cartridge papers. ${ }^{38}$ There are two reasons why this mill might have been regarded as Upper Canadian. The first is political: the annexation of Montreal was a popular notion in Upper Canada from the late 1820 s until the union of Upper and Lower Canada in I84I. St. Andrews, located between the Upper Canadian border and Montreal, would certainly have been included in such an annexation. The second reason is geographic: St. Andrews was separated from Upper Canada only by the Ottawa River.

The need to gather even ghosts connected with the use and making of paper is analogous to the task of the early papermaker who combined fragments and scraps into a useful product. A didactic piece in the Canada Spelling Book encouraged readers to emulate the virtuous child by playing a role in this important process: 
She does not like to waste anything. - She never throws away ... little bits of muslin or linen, or ends of thread; ... She has seen the man go about gath-er-ing rags, which her mother has told her he sells to people who make paper of them. ${ }^{39}$

The bibliographer studying paper must also gather fragments to be analyzed then combined within a framework provided by bibliographic precedent. Only when patterns of supply and print shop practices have been clarified can paper be used as evidence in the analysis of bibliographic problems such as attribution and false dating.

NOTES

I. Roy Stokes, 'Descriptive Bibliography: Its Definition and Function,' Papers of the Bibliographical Society of Canada i 8 (1979): 19-25.

2. A useful review is found in G.T. Tanselle's 'The Bibliographical Description of Paper', Studies in Bibliography 24 (1971): 27-67; reprinted G.T. Tanselle, Selected Studies in Bibliography (r979), pp. 203-43.

3. Toronto was known as York from the arrival of John Graves Simcoe in 1793 until incorporation in 1834 , when the earlier name was restored.

4. Erin Patricia Lockhart Fleming, 'A History of Publishing in Toronto, 1798 to I84I, with a Descriptive Bibliography of Imprints' (PH.D. thesis, University of London, I980).

5. Stokes, p. $2 \mathrm{I}$.

6. The York Almanac and Royal Calendar of Upper Canada (1823), p. I 58.

7. Letters from an American Loyalist in Upper-Canada (18Io) OTMCL, OTU.

8. Upper Canada, Arbitrator appointed to hear and determine all claims of the Province of Upper Canada upon the Province of Lower Canada, Report (I823) OTMCL; Upper Canada, Legislature, Joint committee ... on the subject of the importation of tea into this province, Report (I824) OTMCL, OOA.

9. Upper Canada, House of Assembly, Journal (I80I) OTMCL.

Io. The York Almanac and Provincial Calendar (I82I) OTMCL; Statutes of Upper-Canada (I82I) oTU.

II. Letters from Mr. Commissioner Robinson (1823) OTMCL.

I2. OTMCL.

I3. OTAR.

I4. Edward Heawood, Watermarks (I950), p. 3I.

15. 6th George Iv chapter 73.

16. The most recent outline is found in J.A. Blyth, "The Development of the Paper Industry in Old Ontario, I824-1867,' Ontario History 62 (I970): I19-33.

17. The Upper Canada Almanack (1815), p. I6.

18. The York Almanac and Royal Calendar of Upper Canada (1823), p. 63.

19. Archives of Ontario, Mackenzie-Lindsey Papers, W.L. Mackenzie Correspondence, I2 Dec. 1825, Crooks, James (West Flamboro') to William Lyon Mackenzie (York).

20. Upper Canada, House of Assembly, Journal (1826), p. 45.

2I. Ibid., p. 108.

22. Archives of Ontario, Mackenzie-Lindsey Papers, 20 March 1826.

23. Ibid., 28 March 1826.

24. Ibid., I6 May 1826.

25. Henry Cook Todd, A Manual of Orthoepy (1833), p. iv; p. 68.

26. Upper Canada, House of Assembly, Journal: Appendix (1831), p. 177. 
27. Ibid. (I833), p. I33.

28. Ibid. (I834), p. I59.

29. Ibid. (I836), p. 5 II

3o. Ibid. (I837), p. 572 .

31. Upper Canada Religious Tract and Book Society, Fourth Report (I836), p. I3.

32. Toronto Auxiliary Bible Society, Seventh Report (1836), p. I2.

33. Upper Canada, House of Assembly, Journal: Appendix (I835), p. ${ }^{11} 22$.

34. The Toronto Almanac and Royal Calendar of Upper Canada (I839), p. I27.

35. Upper Canada (Acts) (r830), no. 667.

36. Upper Canada, House of Assembly, Journal: Appendix (1833), p. 7.

37. Henry Cook Todd, Notes upon Canada and the United States of America (1835), p. 77.

38. Canadian Spectator, November 6, 1822.

39. Alexander Davidson, [Canada Spelling Book] (I84-), p. 8I.

KEY TO LOCATION OF COPIES CITED

OOA Public Archives of Canada, Ottawa

OTAR Archives of Ontario, Toronto

OTMCL Metropolitan Toronto Library

OTU University of Toronto Library 